\author{
Alexandra Ana Csavdari' ${ }^{(D)}$, A.K. Mynbayeva ${ }^{2}{ }^{(D)}$, G.S. Minazheva ${ }^{2 *}$, M.S. Sadyrova ${ }^{2}$ \\ ${ }^{1}$ Babeş-Bolyai University of Cluj-Napoca, Romania, Cluj-Napoca \\ ${ }^{2}$ Al-Farabi Kazakh National University, Kazakhstan, Almaty \\ * e-mail: Gulsharat.Mynazheva@kaznu.kz
}

\title{
LEADERSHIP AND CONNECTIVISM IN THE ACADEMIC ENVIRONMENT OF UNIVERSITIES
}

The article is devoted to the consideration of the problems of educational leadership in the academic environment. The new trend is aimed at the connectivist development of the structure of interaction between members of the organization, which creates advantages for the development of new scientific and innovative products of the university. The aim of the research is to analyze management styles and leadership in higher education. On the basis of a questionnaire, a test survey and diagnostics of situational-personal orientations, personal qualities and management styles, as well as the conditions for the formation of leadership and leadership potentials of leaders of different levels of management of a national university were analyzed. Shown are effective management methods at different structural levels of the university and considered the possibilities for proactive actions, which are owned by the leaders of the leading university with further extension to other universities.

It has been established that implementation of the managerial leadership principle is an important element in improving the efficiency of managers' activities, therefore, effective management of the university and ensuring the quality of education in general. It is shown that the approach to stimulating effective management in Kazakhstani universities is underdeveloped. Along with this, it should be noted that development of the collective potential of leadership groups and educational leadership is limited. This all requires further discussion, deep analysis and appropriate measures.

Key words: leadership, leader, educational leadership, managerial leadership, higher education, university, academic environment.

\section{Alexandra Ana Csavdari ${ }^{1}$, А.К. Мыңбаева ${ }^{2}$, Г.С. Минажева ${ }^{2 *}$, М.С. Садырова ${ }^{2}$ \\ ${ }^{1}$ Бабеша-Бойяи университет, Румыния, Клуж-Напока қ. \\ ${ }^{2}$ Әл-Фараби атындағы Қазақ ұлттық университеті, Қазақстан, Алматы қ. \\ * e-mail: Gulsharat.Mynazheva@kaznu.kz}

Университеттердің академиялық ортасындағы көшбасшылық және коннективизм

Мақала академиялық ортадағы білім берудегі көшбасшылық мәселелерін қарастыруға арналған. Жаңа тенденция университеттің жаңа ғылыми және инновациялық өнімдерін шығара алу мүмкіндіктерін қалыптастыратын ұжым мүшелерінің өзара әрекеттесу құрылымын коннективистік дамытуға бағытталған. Зерттеудің мақсаты - жоғары білім берудегі басқару және көшбасшылық стилдерін талдау. Сауалнама, тесттік сауалнама және жағдайлық-тұлғалық бағдарларды диагностикалау нәтижелері негізінде, жеке қасиеттер мен басқару стильдері, сондай-ақ ұлттық университетті басқарудың әр түрлі деңгейіндегі көшбасшылардың көшбасшылығы мен әлеуетін қалыптастыру шарттары талданды. Университеттің әр түрлі құрылымдық деңгейлеріндегі тиімді басқару әдістері көрсетілген және жетекші университет басшыларына тән белсенді бастамаларды басқа университеттерге тарату мүмкіндіктері қарастырылған.

Басқарушы көшбасшылық қағидаттарын іске асыру менеджерлердің басқаруы бойынша тиімділігін арттырудың маңызды элементі, соның нәтижесінде университетті тиімді басқару және жалпы білім сапасын қамтамасыз ету бойынша да негізгі элемент болып табылатындығы анықталды. Қазақстандық ЖОО-да тиімді менеджментті ынталандыру тәсілінің дамымағаны, сонымен қатар көшбасшылық топтардың ұжымдық әлеуеті мен білім беру көшбасшылығының дамуы шектеулі екендігі көрсетілген, бұл қосымша талқылау мен терең талдауды және тиісті шараларды қабылдауды қажет етеді.

Түйін сөздер: көшбасшылық, көшбасшы, білім берудегі көшбасшылық, басқарушылық көшбасшылығы, жоғары білім, университет, академиялық орта. 


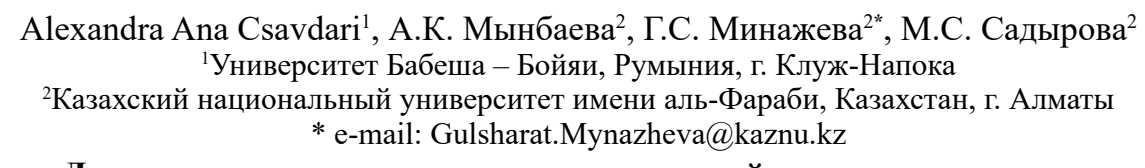

\title{
Лидерство и коннективизм в академической среде университетов
}

\begin{abstract}
Статья посвящена рассмотрению проблем образовательного лидерства в академической среде. Новая тенденция направлена на коннективистское развитие структуры взаимодействия членов организации, которая создает преимущества для разработки новых научных и инновационных продуктов университета. Целью исследования является анализ стилей управления и лидерства в высшем образовании. На основе анкетирования, тестового опроса и диагностики ситуативно-личностных ориентаций проанализированы личные качества и стили управления, а также условия формирования лидерства и лидерских потенциалов руководителей разных уровней управления национального вуза. Показаны эффективные методы управления на разных структурных уровнях вуза и рассмотрены возможности для инициативных действий, которыми владеют лидеры ведущего вуза с дальнейшим распространением на другие вузы.

Установлено, что реализация принципа управленческого лидерства является важным элементом улучшения эффективности деятельности руководителей, как последствие эффективного управления вузом и обеспечения качества образования в целом. Показано, что подход к стимулированию эффективного управления в казахстанских вузах недостаточно развит, а также развитие коллективного потенциала руководящих групп и образовательного лидерства ограничено, что требует дальнейшего обсуждения, глубоко анализа и принятия соответствующих мер.

Ключевые слова: лидерство, лидер, образовательное лидерство, управленческое лидерство, высшее образование, университет, академическая среда.
\end{abstract}

\section{Introduction}

Current situation of the world economy development when the key accent directed on innovations, globalization processes and new challenges, developed countries do not just compete in production field, but in the sphere of knowledge economy and technological ideas. Nowadays education is supposed to be providing conditions of the state's stable social and economic development, and its intellectual capital becomes a strategic factor that defines prospects of development and competitiveness.

It should be noted, that the sphere of education that responds to the problems of society and civilization, should influence and support the development of positive trends in society. One of the important outcome should be finding specific solutions to emerging social contradictions. Implementation of its social and economic functions, for the years of its formation, the higher education system of the Republic of Kazakhstan has undergone serious qualitative and positive transformations. Along with this, the analysis of its current state shows the presence of numerous problems that hinder its development and require solutions. Low efficiency of universities, caused by the lack of managers of higher education trained in the new conditions is one of them. Changes in economic reality of the country have changed the process of managing educational institutions.

There is a strong belief that management of educational systems is a kind of social management, since the object of management is the education system. Society underlines requirements to the manager. It happens due to the factor, that success of the team, the work satisfaction of team members and favorable working conditions depend on the personal qualities of the manager.

In the new digital era of education development, the issues of educational leadership become more relevant. Educational organizations have significant features affecting the management system. The features of connectivist or network structure of interaction organization now supplements the matrix structure of management, operating in higher education institutions. Approach based on connectivism influences the development of university social environment, forms and develops social capital of the university.

\section{Literature Review}

The study of transformational leadership in universities is explained by the fact that the ideas that later become innovations are often born in scientific and educational organizations (P. S. Glukhov, 2013). And according to P.S.Glukhov, the competitiveness of modern organizations depends on the production of knowledge and implementation of innovation. They need managers-leaders who can manage in the deployment of innovative activities. The activity of managers is associated with the management of the development of production, personnel and 
business processes, and when solving tactical and strategic tasks of transformation, they are guided by the choice of certain priorities in management and use a particular leadership style (V. G. GryazevaDobshinskaya et al., 2018).

New postmodern approaches in education show new possibilities of management and development of universities. Benchmarking in organizational management, educational leadership; development of intellectual and social capital of the organization, etc. have become powerful strategies. Benchmarking establishes a framework for continuous development that is achieved by certain actions after best practices are identified, applied, and continually monitored by management (P.H. Meade, 1998). Essentially, benchmarking is «comparing best practices in order to select the best one and apply it to a particular case» (L.A. Krohmal et al. 2019). Identifying the leading universities in the world and working with them, studying their practices and history of achievement is one of the strategies used in higher education.

A.L. Kovaleva defines managerial leadership as «interaction between members of the team, in the center of which there is a leader (dean, head of department, head of structural unit), whose personal qualities largely determine successful and effective activity of this unit, its effectiveness and social significance» (A.L. Kovaleva, 2012). Also researchers of managerial leadership distinguish several styles of leadership: authoritarian (autocratic), democratic, liberal (self-deprecating).

Updated understanding of educational leadership appears in modern studies (F. Corbett, E. Spinello, 2020; N.Yakavets et al., 2015) Educational leadership is associated with the development of leadership qualities of team members as informal leaders, on the one hand, being initiators of creation and implementation of new experience, on the other hand, consolidating the organizational network of educational institutions.

Management psychology, theories of organizational behavior and management reveal rich traditions of organizational leadership: leader personality theory, behavioral approach, situational leadership theory of P. Hersey and C. Blancher, progression to the goal of R. House, substitute leadership concept of S. Kerr and J. Germier, «I-concept» of leadership of B. Shamir, attributive approach, transformational leadership, etc. (L. V. Kartashova, 2018; V.A. Spivak, 2000; N. P. Derzkova, 1999).

Transformational leader unites followers to achieve some higher collective goal, motivates them to move to a higher motivational level, increases their ethical expectations (P.S. Glukhov, 2013, p. 55). Managers with transformational leadership help their employees grow and develop their leadership skills (Bass and Riggio, 2005).

A. Sadeghi and Z.A. Lope Pihie's research shows that academic leaders are associated with transformational leadership and performance (Sadeghi and Lope Pihie, 2012). The authors argue that university employees value managers with a combination of transformational and transactional leadership. The components of leadership styles that are significant predictors of management effectiveness in an educational organization are also noted: idea-generating influence, inspiring motivation, personal approach, intellectual stimulation, noninterference leadership, and active management by deviation exclusion.

B. Bass' concept of multifactor leadership positions «transformational leadership» as the most adequate change management situation in the organization (Dile D., Cangemi J., Kowalski C., 2004, 2007; Avolio B.J., Bass B.M., Jung D.I., 1999).

Gryazeva-Dobshinskaya G.et al., evaluate the potential of transformational leadership and argue that: "Transformational leadership includes such basic style features of leaders' behavior as expansion of subordinates' interests, support of their personal growth and self-esteem, their intellectual and creative stimulation and enthusiasm, encouragement to go beyond short-term individual interests, aspiration for changes corresponding to new significant goals of the collective» (V. G. Gryazeva-Dobshinskaya et al., 2018, - P.113). Thus, in a perfect organization of education it is possible to combine three styles of leadership of heads of departments: managerial, educational and transformational. At the same time, such a combination in one person without professional training is unlikely. In the research we decided to study how university managers of different levels assess their leadership abilities, how they see new perspectives, new potential of the organization's connetivist network.

\section{Let us consider the ideas of Connectivism theory}

Connectivism is a new theory of learning that applies to leadership with a discussion of the yet unexplored possibilities of using connectivism to redefine leadership in the twenty-first century.

F. CorbettandE. Spinellobelieve that connectivism has the potential to be seen as a core competency for effective leadershipin the twenty-first century, and offer 
the following definition: connectivism redefines the leadership paradigm for the 21 st century, recognizing that leadership is a dynamic, connected and collective process of influence, based on the principles of digital knowledge and interpersonal neural networks (F. Corbett, E. Spinello, 2020).

The nature of connectivism is hybrid, interdisciplinary, and raises many interesting questions. Research scholars believe that in addition to establishing connectivism as a theory of learning, future research on the application of connectivism to leadership will be important and could contribute significantly to the evolution of traditional views of leadership from understanding the actions of individual leaders to determining the emergent dynamics of the connected collective. A better understanding of connectivism can be achieved through identifying and quantifying the specific values, behaviors, and technological tools that are associated with connectivist approaches to leadership. In the era of the knowledge economy, as noted by Liang T.Y., Zamulin A., the new leadership is horizontal (not vertical), collegial (not individualistic), consultative (not Command-andControl), bio-logic-based (not machine logic-based) (A. L. Zamulin, 2012; T. Y. Liang, 2007).

In a changing world, there should be no doubt that those who want to achieve quality education should ensure its presence first and give priority to the development of potential leaders (Beare, H., Caldwell, B., \& Millikan, R., 1992). On the other hand, educational leadership contributes to the development of the organizational culture of universities, and the development of «intellectual, organizational, and social capital of the educational organization» (Yakavets, N., 2016). Their unity creates conditions for development/promotion of innovations both in education and in the production of university scientific and innovative products.

The purpose of the article is to analyze management and leadership styles in higher education in the context of globalization processes; to develop recommendations for the formation of social and organizational capital of the university through educational leadership technologies and connectivist approach.

\section{Research methods}

In order to study and describe leadership abilities and leadership style, a three-part test questionnaire was offered to 200 respondents. The respondents were the heads of structural subdivisions of al-Farabi Kazakh National University (KazNU). According to G.G. Yeremeeva, leadership in university is necessary at all levels of management(G.G. Yeremeeva, 2005). Hence, leadership is a component not only indispensable, but also irreplaceable, necessary for association of all personnel for achievement of the general purpose of higher education institution. KazNU has advanced on 436 positions in QS WUR rating since 2010 and took 165 place in 2020 . Such success was provided by modernization of management system based on international standards ISO 9000:2015 (G.S. Minazheva, 2020), implementation of resultoriented management system (RBM) and coordinated teamwork. The University development strategy (www.kaznu.kz) is implemented through RBM and operates the system of indicative planning and rating system of performance assessment of teaching staff, departments and faculties. A unified data management strategy is also implemented to ensure effective decision-making (G.M. Mutanov et al., 2020).

In the questionnaire, the sample was distributed:

(a) gender: $77.5 \%$ women and $22.5 \%$ men;

(b) management experience: none $-16 \%$; up to 5 years $-37 \%$; 6 to 15 years $-30.5 \%$; 16 to 25 years $-11 \%$; 26 to 35 years $-3 \%$; over 36 years $-2.5 \%$;

(c) age: 20 to 29 years $-13 \%$; 30 to 39 years $26 \%$; 40 to 49 years $-28.5 \%$; 50 to 59 years $-20.5 \%$; 60 to 69 years $-10.5 \%$; 70 to 79 years $-1.5 \%$;

(d) tenure at the level of: department $-79 \%$; faculty $-7 \%$; university $-14 \%$. This is explained by the fact that the department is the nucleus of the entire educational process, research and educational activities of the university.

\section{Results and discussion}

According to the results of the questionnaire, it was found that among the respondents only $17 \%$ of the respondents have a management/ managerial education. This indicates that most of them were not specially trained, and they gained managerial skills from their own work experience. According to respondents, they adhere to management style: authoritarian $6 \%$; democratic - 79\%; liberal - 9.5\%. Also $3 \%$ of respondents adhere to a mixed style of management depending on the situation.

The majority of the respondents (>60\%) mentioned the following qualities inherent in a leadermanager: decisiveness, ability to make decisions independently and timely and take responsibility in critical situations; reliability, ability to keep your word and protect your subordinates; strong-willed character, ability to overcome obstacles on the way to the goal; exactingness towards oneself and others, ability to evaluate the results of work, etc. 
The results of the analysis of the test surveys are recommended to be used to support the leadership of the heads of structural units and to be taken into account in the training of their followers. Also it is necessary to take into account and carry out training sessions on leadership development.

According to the results of the analysis of leadership problems in higher education, it was revealed that not only managers, but also every employee has leadership qualities. Consequently, the problem of the relationship between the formal leader and the informal leader deserves special attention. The effectiveness of innovation implementation in the educational process largely depends on the motivational structure and professional values of the informal leader.

1 . The study shows the need to train experienced leaders in the educational system. Only $5.5 \%$ of respondents have special education of a manager, $21.0 \%$ of respondents have experience of managerial work from 26 to 36 years. This group is characterized by a high level of competence in both professional and managerial activities. They are real leaders capable of preparing and training a new generation of followers. This group includes representatives of the rectorate and faculties.

The second group has managerial experience from 6 to 25 years $(41.5 \%)$, which includes mainly middle managers. Their leadership qualities are manifested in the execution of the top management assignment. If the first group of leaders needs the qualities of strategic planning, forecasting, designing based on the labor market demand and calculating the risks in the process of implementation of new educational programs, the second group of leaders is focused on organization, coordination of execution of specific tasks considering the real capabilities of the teaching staff. The middle group of respondents includes respondents from 40 to 59 years old. This group includes representatives of departments of faculties. The department is the nucleus of the completely educational process, research and educational activity of the university. Consequently, the cultivation of leaders in higher education begins with the departments.

The third group of respondents consists of leaders in management who have up to 5 years of experience (37\%) and employees who have recently joined the group of junior managers (16\%). According to the results of the study this group includes respondents aged 25 to 29 years. It was found that only $17 \%$ of the respondents have an education in organization management; corporate governance; management in education system; business economics and managerial courses, etc., Therefore, in the leadership of higher education we should pay more attention to those who have no experience or insufficient experience in management in higher education. A special role here is played by the system of professional development retraining through special courses on management in higher education and human resource management. We believe future educational programs should introduce courses on social relations in the team, social management. The specialist of the new format should know the basics of social management.

2 . The study revealed a gender asymmetry in the use of leadership qualities and potential of university employees. As in all educational institutions, women prevail in higher education institutions. In addition, $77.5 \%$ of women and $22.5 \%$ of men are involved in managerial activities. The asymmetry is expressed in the fact that men $(99.0 \%)$ predominate at the highest level of management. Potential opportunities of women are mainly realized in the middle level of management.

3 . The levels of manifestation of leadership qualities of respondents at the level of university, faculty and department were revealed.

At the department level, leadership qualities are mostly expressed at an average level $(60.0 \%)$. That is, only about $10.0 \%$ of employees have the most prominent leadership qualities, and in $30.0 \%$, they are not observed or weakly expressed at all. It was revealed that the selection of managerial staff at all levels of management in the system of higher management is mainly based on objective criteria, without taking into account psychological, communicative, moral and ethical parameters of the applicant. The work experience and achievements in scientific and teaching activities are not always indicators of his leadership qualities.

We were interested to find out what definition respondents give to the concept of «Leadership». The results of the survey show that $70 \%$ of the respondents believe leadership is having influence and the ability to draw others to action (Fig.1). $11 \%$ of respondents believe that leadership is about success and authority. And only 19\% of the respondents believe that it is not only success and authority, but also the possession of influence and the ability to enthuse other people to action. According to $84.8 \%$ of the respondents the concepts of leader and manager are not identical, i.e. not every manager can be a leader, and $7.6 \%$ of the respondents believe that a manager is already a leader by default and also $7.6 \%$ of the respondents believe that not every manager can be a leader, but an effective manager can become a leader. 


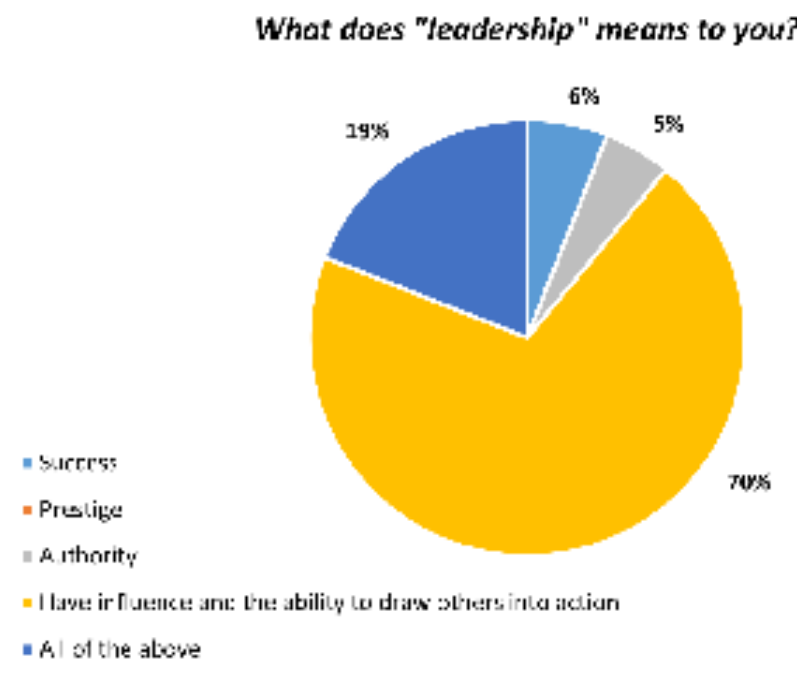

Figure 1 - Respondents' definition of Leadership

In the opinion of $96 \%$ of respondents, education and professional competence are the most important for the manager, $70 \%$ of them note combining these qualities with leadership, innate talent for leadership, high intelligence and creativity, life experience and practice, $35 \%$ of respondents noted combining them with the qualities of will, only $15 \%$ - with emotional maturity. The remaining $4 \%$ of respondents consider the following as the most important for a manager high intellect and creativity, volitional qualities, responsibility, life experience and practice.

To achieve the objectives set for the manager, according to the respondents, the manager needs the following competences: first of all, strategic vision; the ability to make effective decisions; high interpersonal communication skills; experience in solving complex problems; breadth of thinking and openness to people.

The role of the teaching staff in the managerial activity of the department/faculty/university was evaluated by the respondents as follows: $46 \%-$ respondents as high; $38 \%$ as average; equal numbers of respondents $(8.4 \%$ and $7.6 \%$, respectively) indicated as insignificant and low.

The majority of respondents $(65 \%)$ indicated that all faculty members are involved in decisionmaking, $27 \%$ of respondents indicated that faculty members are not always involved, and $8 \%$ indicated that faculty members are not involved.

Respondents emphasize that pressing problems are widely discussed at weekly meetings of the department, dean's office and rectorate, at the
Faculty and University Academic Council. They include active participation of all members of the team with the participation of members of the Academic Council from among the students. Collegial decisions are made in all areas of activity and tasks. Also the development strategy and action plan of each specific structural unit are developed, recommendations and suggestions are made, each teacher is responsible for his area of work and has the opportunity to express his opinion and put forward his idea.

The vast majority of respondents $(65 \%)$ noted that the university staff is characterized by openness to change, the ability to derive lessons from experience and successfully apply them in new or non-standard situations; $57.7 \%$ describe the staff as having the ability to explore new options and solutions, the ability to achieve results in new or (and) more complex situations, having the desire to constantly «raise the bar»; $42 \%$ of respondents noted that the staff has the desire to initiate and lead change processes (Fig.2). 23\% of respondents deny that the staff is open to change; $27 \%$ of respondents believe that the staff lack the ability to achieve results in new and/or more challenging situations and are unable to learn from experience and successfully apply it in new or unconventional situations; $31 \%$ believe that the staff lack the desire to constantly «raise the bar» and $46 \%$ of respondents indicated that the staff lack the desire to initiate and lead change processes. The percentage of respondents who found it difficult to answer ranged from $6 \%$ to $18 \%$.

Answering the question of what a modern leader should look like, the respondents noted the 


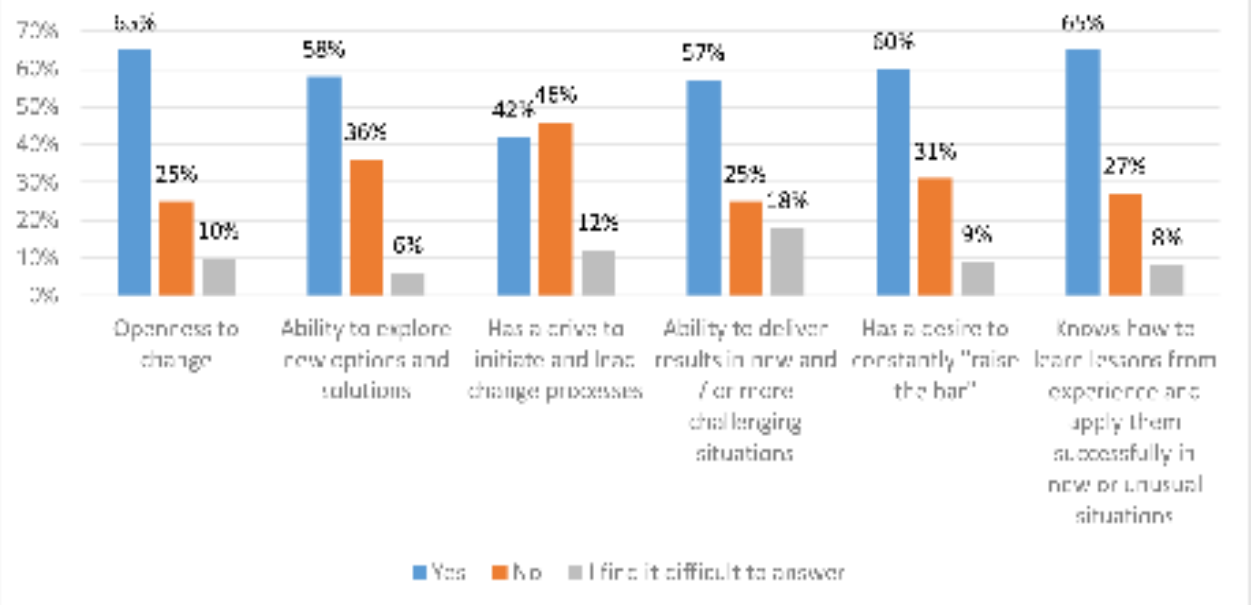

Figure 2 - Respondents' openness to change

following qualities: to be able to direct the work of their wards to achieve the goal $(69.2 \%)$, to be an effective manager (73\%), to give an objective assessment of the work done by the subordinates (38.5\%), to promote the career of their colleagues (wards) (30.8\%), to act as a coach motivator (15.4\%) help their colleagues (wards) (3.8\%). The results of the study show that the modern leader must have professional qualities as a manager and as a coordinator in the development of professional potential of the team and motivator to achieve the goal of the organization. The modern leader should possess physical, professional, psychological and moral potential.

The purpose of the research was also to find out whether the university leaders have these qualities.

The first group of respondents are committed to the highest level of ethics, tact, and responsibility. In addition, $85.0 \%$ of the respondents answered that they possess all of the above qualities of a leader. This group of respondents can be characterized as leaders of educational management.

The second group of respondents is characterized by less active manifestation of leadership qualities. Their passivity is manifested by low assessment of their own leadership qualities, they are not persistent and not determined, they have a slow reaction and lack rationality, they cannot adapt in innovative changes. This group needs to further develop management skills and use their potential skills effectively. Apply more motivational and educational, consultative methods to improve the leadership skills of the interviewees.
A small part of the respondents belongs to the third group. These employees show little managerial qualities, do not comply with ethical norms, do not accept criticism, have subjective opinions, and cannot predict difficulties in advance.

Most of this group is characterized by the lack of experience due to their young age but they have great potential as a professional and manager. It is necessary to create conditions for the development of managerial skills.

\section{Conclusion}

Studies concerning the strategic role of «managerial leadership» in ensuring the quality of education and development of academic environment in universities focused on the disclosure of problems of managerial leadership of heads of structural units of different levels, which affect the effectiveness of the university and the quality of education. We believe that the implementation of the principle of managerial leadership is an important element in improving the performance of managers, consequently, the university and the quality of education. Based on the test survey, opportunities for proactive and independent action are identified. Leaders grow through experience and support; their active development can increase the leadership qualities of the system as a whole. Maximizing leadership capabilities means that the selection and development of leaders is an integral part of the work of the university and the system, rather than a discrete process. 
The approach to performance management and incentives has been found to be underdeveloped. The development of the collective potential of leadership teams, rather than the individual potential of leaders, educational leadership, is still limited, despite numerous statements and studies suggesting that collective potential is a greater driver of performance than individual potential.
From our findings, we conclude that «managerial leadership» in higher education, is a management strategy, a strategy for developing leadership and the institution. Therefore, managers must be personally and actively involved in addressing the «learning and research complex»; implementing an integrated communication system, educational leadership; and using the full potential of staff at all levels.

\section{References}

Avolio B.J., Bass B.M., Jung D.I. Re-examining the components of transformational and transactional leadership using the Multifactor Leadership Questionnaire. In: Journal of Occupational and Organizational Psychology, 1999, vol. 72, iss. 4, pp. 441-462.

Bass, B.M. Transformational Leadership / B.M. Bass, R.E. Riggio. - 2005. - 296 p

Beare, H., Caldwell, B., \& Millikan, R. (1992). Creating an Excellent School. London: Routledge.

Bgashev, M. V. (2018). Critical analysis of the personality and management style of the head of a modern higher education institution. Economac Development Research Journal, 12. http://edrj.ru/article/01-11-2018

Bryk, A., \& Schneider, B. (2002). Trust in schools: A core resource for improvement. New York, NY: Russell Sage. 240.

Corbett F., Spinello E., 2020. Connectivism and leadership: harnessing a learning theory for the digital age to redefine leadership in the twenty-first century. https://doi.org/10.1016/j.heliyon.2020.e03250

Derzkova N.P. Didactic conditions for the formation of an effective style of management of educational institutions: authorref ... Ph.D.in Ped science - M., 1999 . - 28 p.

Dile D., Cangemi J., Kowalski C. [Transformational Leadership: A Brief Overview]. In: Psikhologiya. Zhurnal Vysshei shkoly ekonomiki [Psychology. Journal of the Higher School of Economics], 2004, vol. 1, no. 1, pp. 96-109.

Dile D., Cangemi J., Kowalski C. [Transformational leadership]. In: Psikhologiya sovremennogo liderstva: amerikanskie issledovaniya [The psychology of modern leadership: American studies]. Moscow, Kogito-TSentr Publ., 2007, pp. $23-37$.

Eremeeva, G.G. (2005). Innovation environment as a factor in the functioning and development of the quality management system in the university // Materials of the VI international scientific and methodological conference: Quality of education: management of achievement, problems (EQ-2005), Education Quality EQ-2005. - Novosibirsk, 177-180.

Glukhov P.S. Leadership styles in innovation: phenomenology and empirical research // Psychology. Psychophysiology. - 2013. - T. 6. - No. 4. - P.53-60.

Gryazeva-Dobshinskaya V.G., Dmitrieva Yu. A., Markina NV Transformational leadership and strategic management attitudes of managers // Bulletin of the Moscow State Regional University. - 2018. - No. 3. - C.111-132

Kartashova L. V., Nikonova T. V., Solomanidina T. O. Organizational behavior // M .: INFRA-M. - 2001 .-- S. 190;

Kovaleva AL Leadership in the educational process // Bulletin of the University. - 2012. - No. 3.

Krokhmal L. A., Fefelova A. A., Bakuma D. A. Benchmarking: a tool for assessing the effectiveness and ensuring the development of national systems of higher education // Economy Profession Business. - 2019. - No. 3. - P.48-56.

Kuraev, A. (2016). Soviet higher education: an alternative construct to the western university paradigm. Higher Education. 71. $181-193$. Liang T. Y. The New Intelligence Leadership Strategy for iCAS Thow Yick // Human Systems Management. 2007. Vol. 26. P. 111-122

Meade P. H. A guide to benchmarking. The University of Otago 1998.: https://planning.curtin.edu. au / local / docs / Guide_to_ Benchmarking_Oct2007.pdf (дата обращения: 17.03.2018).

Minazheva, G. S. (2020). Modern trends in the formation of the quality system of higher education. E3S Web of Conferences Volume 159. The 1st International Conference on Business Technology for a Sustainable Environmental System (BTSES-2020) Almaty, Kazakhstan, (March 19-20).

Mkrtychyan G. A. Organizational behavior// https://studme.org/113515/menedzhment/organizatsionnoe_povedenie, 2018;

Mutanov G., Mamykova Zh., Kopnova O., \& Bolatkhan M. (2020). Applied research of data management in the education system for decision-making on the example of Al-Farabi Kazakh National University. E3S Web of Conferences Vol. 159. The 1st International Conference on Business Technology for a Sustainable Environmental System (BTSES-2020) Almaty, Kazakhstan, (March 19-20).

Spivak V.A. Organizational behavior and personnel management // SPb .: Peter. - 2000. - T. 200. - S. 416;

Sadeghi, A. Transformational Leader ship and Its Predictive Effects on Leadership Effectiveness / A. Sadeghi, Z.A. Lope Pihie // International Journal of Business and Social Science. - 2012. - Vol. 3, No. 7. - P. 86-97.

Yakavets N., Frost D. \& Khoroshash A. (2015): School leadership and capacity building in Kazakhstan, International Journal of Leadership in Education, DOI: 10.1080/13603124.2015.1066869

Yakavets, N. (2016). Societal culture and the changing role of school principals in the post-Soviet era. Journal of Educational Administration.

Zamulin A.L. Leadership in the era of knowledge // Bulletin of St. Petersburg University. Management. - 2012. - No. 3; 